\title{
The Effect of Temperature on Recovery of Buoyancy by Microcystis
}

\author{
By R. H. THOMAS AND A. E. WALSBY* \\ Department of Botany, University of Bristol, BS8 1UG, UK
}

(Received 11 October 1985; revised 18 February 1986)

\begin{abstract}
Colonies of Microcystis in Abbots Pool, Avon, UK, were found to regulate their buoyancy according to light (photon flux density). The autumnal decline of the population was associated with an increase in the proportion of colonies that were non-buoyant, and with declining temperatures in the pond. Non-buoyant colonies taken from the pond regained buoyancy in the dark rapidly at $20^{\circ} \mathrm{C}$ but only slowly at $12{ }^{\circ} \mathrm{C}$ and below. A laboratory strain of Microcystis behaved in a similar manner. Comparisons of the behaviour of this organism placed at $8{ }^{\circ} \mathrm{C}$ and $20^{\circ} \mathrm{C}$ were made; in high photon flux density buoyancy was lost at both temperatures due to accumulation of dense carbohydrate. When transferred to the dark cells at $20^{\circ} \mathrm{C}$ became buoyant again as carbohydrate was utilized and more gas vesicles were made; at $8^{\circ} \mathrm{C}$ much less carbohydrate was used and no increase in gas-vacuolation occurred. The failure to regain buoyancy in the dark at low temperatures accounts for the loss of buoyancy and sedimentation of the Microcystis in Abbots Pool.
\end{abstract}

\section{INTRODUCTION}

Microcystis is one of the most widespread and successful of the planktonic cyanobacteria and is well known for the formation of surface water-blooms (Reynolds \& Walsby, 1975). It has been established that in temperate zones Microcystis populations reach a maximum in late summer and autumn before many of the colonies fall to the lake sediments where they overwinter in the vegetative state (e.g. Reynolds \& Rogers, 1976; Fallon \& Brock, 1981; Takamura et al., 1984). The accumulation of colonies in sediments must result from increased excess density of the colonies, which are usually buoyant owing to the presence of gas vesicles in their cells.

A colony in the plankton must remain non-buoyant for sufficiently long to reach the lake bottom if it is to be lost by sedimentation. The possible causes of autumnal buoyancy loss have been discussed previously (Reynolds et al., 1981; Oliver et al., 1985). Oliver et al. (1985) found that buoyant Microcystis colonies fell out of the water column in one of the Blelham Tarn Lund tubes because of precipitation with a heavy iron-containing colloid that formed when iron-rich water of the hypolimnion became oxygenated. However, this mechanism cannot apply universally because it depends on the presence of large quantities of iron (or possibly other elements such as manganese) and a suitably high $\mathrm{pH}$ to allow precipitation of the oxidized metal.

Cells in Microcystis cultures are able to regulate their buoyancy according to photon flux density (Thomas \& Walsby, 1985). It was quantitatively shown that in bright light the density of cells increased sufficiently to cause loss of buoyancy, primarily because of carbohydrate accumulation. Kromkamp \& Mur (1984) showed that in cultures kept on light/dark cycles there was a close correlation between changes in buoyant density of cells and their carbohydrate content. In more general terms, it has been held that buoyancy in cyanobacteria depends on an interaction of light and limiting nutrients that affects the relative rates of photosynthesis, growth and gas vesicle synthesis (Walsby, 1977; Klemer et al., 1982). Temperature will also affect these processes, but no investigations have been made into its effects on buoyancy. Most laboratory experiments on buoyancy have been done at $20^{\circ} \mathrm{C}$ or higher, while cyanobacteria in nature are frequently present at temperatures well below the optima for photosynthesis and growth (Konopka \& Brock, 1978; Krüger \& Eloff, 1978). 
Sedimentation of Microcystis populations is associated with declining water temperature (see data of Renolds \& Rogers, 1976; Rother \& Fay, 1977; Takamura et al., 1984), but temperature changes have not previously been shown to cause loss of buoyancy. In this paper direct evidence is presented for light-mediated regulation of buoyancy in a natural population of Microcystis and for the involvement of low temperature in the seasonal loss of buoyancy.

\section{METHODS}

Natural population. (i) Site. Abbots Pool is a small eutrophic pond near Bristol (grid reference ST 535734). It has been described in detail by Moss (1969); it measures $40 \times 100 \mathrm{~m}$ and has a maximum depth of $4 \mathrm{~m}$. A Microcystis bloom was present in the autumn of 1984 .

(ii) In situ incubation experiments. Samples of Microcystis were concentrated by towing a plankton net $(100 \mu \mathrm{m}$, mesh) and were incubated in $100 \mathrm{ml}$ conical flasks stoppered with rubber bungs and clipped to wooden battens that were suspended at required depths on a rope anchored at one end and buoyed at the other. Dark bottles were flasks that had been painted black. Buoyancy of colonies was determined with minimum delay by counting floating and sinking colonies in a Lund counting cell. The Lund cell is a normal microscope slide, with the edges raised $0.5 \mathrm{~mm}$ on which a $22 \times 55 \mathrm{~mm}$ coverslip can be placed; a sample of $0.62 \mathrm{ml}$ volume is pipetted under the coverslip. The principle of operation is the same as the haemocytometer method of Walsby \& Booker (1980).

(iii) Sampling and counting. Depth profiles were taken at a station at the deepest point of the pond, using a $200 \mathrm{ml}$ water sampler. Samples were taken at $0.5 \mathrm{~m}$ intervals from the surface to $3.5 \mathrm{~m}$. When required, sediment samples were obtained by disturbing the soft sediment with the water sampler before closing it. The temperature of samples was determined immediately using a mercury thermometer. Samples of known volume were concentrated to a measured volume by drawing off water with a $50 \mathrm{ml}$ syringe, the nozzle end of which had been cut off and replaced with nylon mesh, pore size $15 \mu \mathrm{m}$, tightly held on with elastic bands. This allowed backwashing of the mesh. The buoyancy and numbers of colonies in the concentrated samples were then determined simultaneously using the Lund cell as described above.

(iv) Traps. Colonies sedimenting out of the water column were trapped in plastic buckets that were weighted on the bottom of the pond and attached to surface marker buoys.

(v) Temperature experiments. Colonies collected from the pond were incubated in dark McCartney bottles at various temperatures. Buoyancy of colonies was determined as described above.

Culture experiments. (i) Culture. Microcystis BC $84 / 1$ was grown at $20^{\circ} \mathrm{C}$ in BG11 medium; this is not the same strain as the Microcystis in Abbots Pool. Details of the culture and the methods below are given by Thomas \& Walsby (1985).

(ii) Buoyancy. The percentage of cells floating was determined after centrifuging cell suspensions in horizontally placed Microslides (Thomas \& Walsby, 1985). Microslides are capillary tubes with a rectangular cross section and flat side walls that allow undistorted microscopical observation.

(iii) Gas vesicles and cell density. Gas vesicle collapse pressure distributions were determined using a pressure nephelometer as described by Walsby (1980). The volume occupied by gas vesicle gas space in cell suspensions was measured with a capillary compression tube (Walsby, 1982). Cell densities were determined on continuous gradients of Percoll (Oliver et al., 1981) using the modifications of Thomas \& Walsby (1985).

(iv) Cell constituents. Dry weight was determined using Whatman GF/C filters and a Cahn electrobalance (four replicates). Carbohydrate was measured with the anthrone reagent (Herbert et al., 1971). Protein was assayed using BCA Protein Assay (Pierce Chemical Co.) and bovine serum albumin standards in a colorimetric test for copper(I), which is generated when copper(II) reacts with protein under alkaline conditions.

(v) Light/dark cycles. Light was supplied to cultures on timed cycles from fluorescent tubes underneath the culture flasks. The mean photon flux density in cultures was determined by the method of Van Liere \& Walsby (1982) using a Macam quantum sensor (sensitive to wavelengths between 400 and $700 \mathrm{~nm}$ ).

\section{RESULTS}

\section{Diel buoyancy changes in early autumn}

During October 1984 it was found that the buoyancy of Microcystis colonies near the surface of Abbots Pool changed at different times of day. This was shown by the following experiments.

Concentrated samples of buoyant Microcystis colonies collected in a net tow were incubated in duplicate bottles at each of 0,1 and $2 \mathrm{~m}$ depth from $10.45 \mathrm{~h}$ to $16.00 \mathrm{~h}$ on 9 October. The proportion of buoyant colonies was determined at $16.00 \mathrm{~h}$ and again on the following morning at $09.00 \mathrm{~h}$ after dark incubation overnight. The results (Table $1 a$ ) showed that in the surface samples many colonies lost their buoyancy during the day and most regained it at night; at $1 \mathrm{~m}$ 


\title{
Table 1. Proportion of Microcystis colonies floating after incubation in light or dark and at different depths
}

\begin{abstract}
(a) Concentrated samples of colonies were incubated in flasks in Abbots Pool at three depths for $5 \cdot 25 \mathrm{~h}$. The sample from the surface was further incubated in the dark in the laboratory for $17 \mathrm{~h}(9$ October 1984). (b) Concentrated samples were incubated in light and dark bottles at the surface of Abbots Pool for $4.7 \mathrm{~h}$ (10 October 1984).
\end{abstract}

$$
\begin{aligned}
& \text { Samples } \\
& \text { (and time) }
\end{aligned}
$$

(a) Initial $(10.45 \mathrm{~h})$

Surface $(16.00 \mathrm{~h})$

$1 \mathrm{~m} \quad(16.00 \mathrm{~h})$

$2 \mathrm{~m} \quad(16.00 \mathrm{~h})$

Surface $(09.00 \mathrm{~h})$

(b) Initial $(12.00 \mathrm{~h})$

Light $\quad(16.40 \mathrm{~h})$

Dark $(16.40 \mathrm{~h})$

\author{
Percentage of \\ colonies floating
}

99
49
99
99
92
98
54
100

Number of

colonies counted

and $2 \mathrm{~m}$ buoyancy was not lost. It was subsequently found that only $3 \%$ of incident light penetrated to $1 \mathrm{~m}$ and $0 \cdot 1 \%$ to $2 \mathrm{~m}$.

The importance of light in buoyancy loss was conclusively established by comparing the buoyancy of colonies in light and dark bottles suspended at the surface of the pool on 10 October (Table $1 b$ ); as before, many colonies lost buoyancy in the light, but none did in the dark. Gas vesicle collapse pressure curves showed that the median critical pressure of gas vesicles in cells with no turgor pressure was $0.73 \mathrm{MPa}$ and that the weakest gas vesicles collapsed at $0.55 \mathrm{MPa}$. The highest average turgor pressure reached in any of the experiments was $0.47 \mathrm{MPa}$, which was insufficient to cause collapse of any gas vesicles.

Buoyancy changes by colonies free in the pool could also be seen. Fig. 1 shows data from depth profiles taken at $10.45 \mathrm{~h}$ and $16.45 \mathrm{~h}$ on a bright day (16 October 1984). At each station between the surface and $2 \mathrm{~m}$ depth the proportion of colonies floating had declined during the day. A decrease in the number of colonies in samples near the surface had also occurred.

\section{The autumn decline of Microcystis}

The abundance of Microcystis in Abbots Pool, estimated by taking depth profiles with stations at $0.5 \mathrm{~m}$ intervals, is shown for the period from 9 October 1984 to 29 November 1984 in Fig. 2(a). The percentage of colonies floating is also shown (Fig. $2 b$ ); it will be noted that the decline of the population coincided with a decrease in the proportion of colonies that were buoyant.

Large numbers of colonies were found in buckets that had been left on the bottom of the pool from 7 to 29 November. This suggested that at least part of the population decline was due to colonies falling out of the water column onto the sediments. In order to test whether the colonies were sinking due to attachment of extraneous material to them (as found by Oliver et al., 1985), colonies collected in a net tow were washed thoroughly on Kleenex tissue. No significant difference in the proportion of colonies floating was found following this treatment.

During the period mid-October to mid-November the proportion of colonies in the water column that were buoyant fell from over $90 \%$ to $35 \%$ (Fig. $2 b$ ). This coincided with a decrease in the water temperature from $12^{\circ} \mathrm{C}$ to $8^{\circ} \mathrm{C}$ (Fig. $2 \mathrm{c}$ ), which suggested that declining temperature might in some way be affecting the buoyancy of colonies.

\section{Effect of temperature on buoyancy changes}

Of colonies collected in net tows on 15 November $49 \%$ were buoyant. An experiment was done to test whether the sinking colonies would regain their buoyancy when incubated in the dark and whether this response was temperature related. Sub-samples were placed in the dark at a range of temperatures and the buoyancy of colonies was determined after 17 and $40 \mathrm{~h}$ (Fig. 3). 


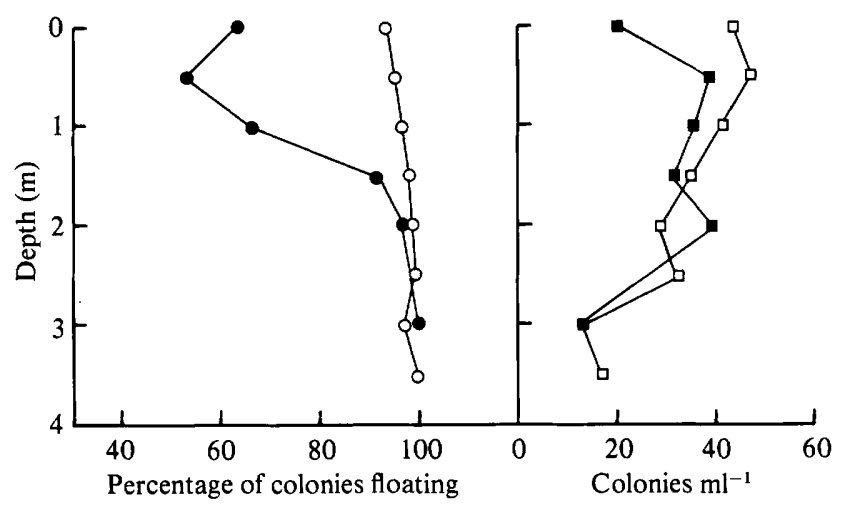

Fig. 1. Percentage of colonies floating $(O, O)$ and number of colonies at different depths $(\square, \square)$ in Abbots Pool on 16 October 1984. Samples were collected at $10.45 \mathrm{~h}(O, \square)$ and at $16.45 \mathrm{~h}(O, \square)$.

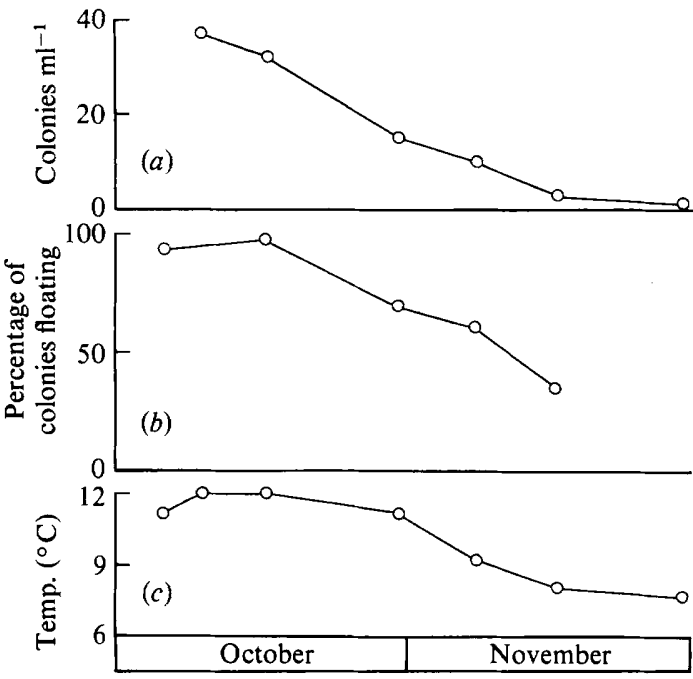

Fig. 2

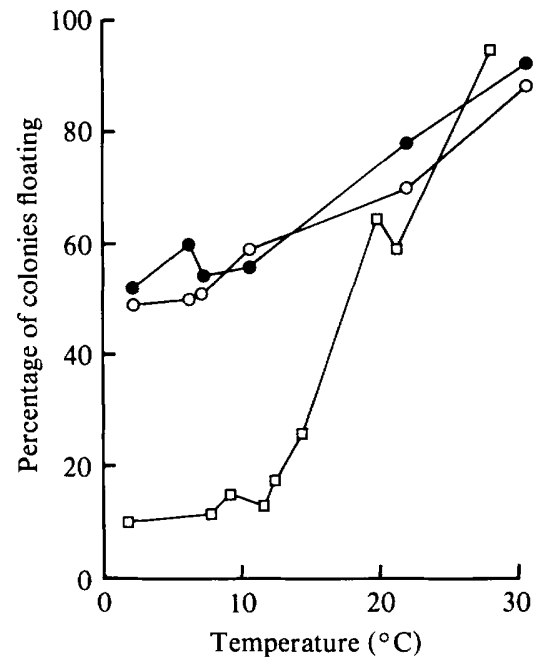

Fig. 3

Fig. 2. Change during October and November 1984 in Abbots Pool of : (a) number of colonies per ml of water (averaged from samples taken at $0.5 \mathrm{~m}$ intervals); $(b)$ the proportion of colonies floating; $(c)$ the average water temperature.

Fig. 3. Proportion of colonies floating after incubation in the dark at a range of temperatures for $17 \mathrm{~h}$ (O) and $40 \mathrm{~h}(\mathrm{O})$. The colonies were collected from Abbots Pool; $49 \%$ were buoyant initially. The lowest line ( $\square$ ) shows the proportion of cells of Microcystis BC 84/1 floating after $24 \mathrm{~h}$ dark incubation (the $95 \%$ confidence limits were within $4.6 \%$ of the mean for each value). Initially cells, grown at a photonflux density of $53 \mu \mathrm{mol} \mathrm{m} \mathrm{m}^{-2} \mathrm{~s}^{-1}$ for $16 \mathrm{~h}$, were $10 \%$ floating.

Recovery of buoyancy was much less at lower temperatures; for example, after $40 \mathrm{~h}$ at $30^{\circ} \mathrm{C}$ $84 \%$ of colonies that were initially non-buoyant had recovered buoyancy, while at $7{ }^{\circ} \mathrm{C}$ only $10 \%$ had recovered buoyancy.

In the next experiment samples in which $66 \%$ of colonies were buoyant were incubated at $7.5^{\circ} \mathrm{C}$ for $26 \mathrm{~h}$ at photon flux densities of 10 and $40 \mu \mathrm{mol} \mathrm{m}^{-2} \mathrm{~s}^{-1}$. Each sample was then divided, one half being incubated at $7.5^{\circ} \mathrm{C}$ and the other at $20^{\circ} \mathrm{C}$ for a further $92 \mathrm{~h}$ in the dark. The proportion of colonies floating at various times is shown in Fig. 4. Most colonies lost buoyancy at both photon flux densities. Little or no recovery of buoyancy occurred at the lower 


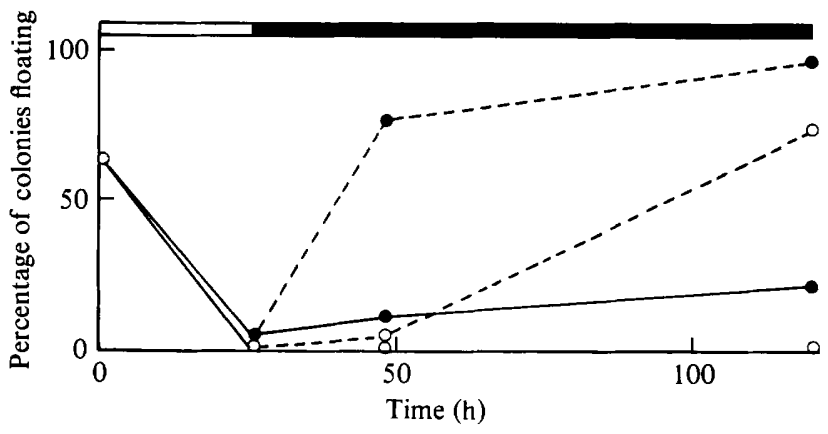

Fig. 4. Changes in the proportion of colonies floating after a light (open bar) and a dark (shaded bar) period, and the effect of temperature on these changes. Samples were exposed to a photon flux density of $10 \mu \mathrm{mol} \mathrm{m} \mathrm{m}^{-2} \mathrm{~s}^{-1}(\mathrm{O})$, or $40 \mu \mathrm{mol} \mathrm{m} \mathrm{m}^{-2} \mathrm{~s}^{-1}(\mathrm{O}) ;-$, incubation at $7.5^{\circ} \mathrm{C}$, - - , incubation at $20^{\circ} \mathrm{C}$. Colonies were collected from Abbots Pool and incubated in the laboratory.

temperature; however, substantial recovery occurred at the higher temperature. There was a pronounced lag before the colonies that had been at the higher photon flux density recovered buoyancy.

\section{Behaviour of colonies in the winter}

Investigation of the colonies collected in the bucket traps showed that over $50 \%$ of them were buoyant and these seemed to be trapped on the bottom of the pool by debris in the sediment. In a sediment sample taken on 15 March 1985 many buoyant colonies were found; the exact proportion that were floating was not determined as non-buoyant colonies could not be reliably counted amongst the surrounding sediment particles.

Throughout the winter a small population of Microcystis was consistently found in the water, averaging about $0 \cdot 5$ colonies $\mathrm{ml}^{-1}$.

\section{Buoyancy changes in laboratory culture}

Since the Microcystis in Abbots Pool was mixed with other algae and zooplankton, detailed measurements to determine the causes of buoyancy change could not be undertaken (unlike the relatively pure population in Blelham Tarn investigated by Oliver et al., 1985). Further studies were therefore undertaken using a laboratory strain of Microcystis, BC 84/1. The relationship between between temperature and buoyancy recovery in the dark of cells that had been exposed to high photon flux density in plotted in Fig. 3. Like the Microcystis in Abbots Pool, the cells in this culture also regained buoyancy more rapidly at high temperatures. Cells of this strain of Microcystis grown at low photon flux densities lost buoyancy at high photon flux density due to an increase in cell density that resulted mainly from carbohydrate accumulation. The following experiment was therefore designed to test the theory that a failure to metabolize carbohydrate at low temperature prevented cells from regaining buoyancy. Cells grown at a photon flux density of about $10 \mu \mathrm{mol} \mathrm{m}^{-2} \mathrm{~s}^{-1}$ were exposed to $50 \mu \mathrm{mol} \mathrm{m}^{-2} \mathrm{~s}^{-1}$ at $8{ }^{\circ} \mathrm{C}$ and at $20^{\circ} \mathrm{C}$ for $18 \mathrm{~h}$. They were then kept at these temperatures in the dark for a further $22 \mathrm{~h}$. Determinations of buoyancy, density after gas vesicle collapse, dry weight, and major cell consitituents (protein, carbohydrate and gas vesicle space) were made (Table 2). On exposure to bright light the two cultures behaved in a similar manner; nearly all cells lost buoyancy and the density of cells increased by about $10 \mathrm{~kg} \mathrm{~m}^{-3}$, from the original value of $1034 \mathrm{~kg} \mathrm{~m}^{-3}$. The dry weight and carbohydrate content both increased significantly, but protein did not change greatly. During the period in the dark, however, the cultures behaved differently from one another. The buoyancy of cells at $20{ }^{\circ} \mathrm{C}$ recovered to $95 \%$ floating, while at $8{ }^{\circ} \mathrm{C}$ it increased to only $16 \%$ floating. The large change in buoyancy at $20{ }^{\circ} \mathrm{C}$ was associated with a $64 \%$ decrease in carbohydrate, a $9 \%$ increase in gas vesicle gas space and a $17 \%$ increase in protein. The magnitude of all these changes was much smaller in the $8{ }^{\circ} \mathrm{C}$ culture; most notably carbohydrate had decreased by only $11 \%$. 
Table 2. Changes in major cell constituents contributing to cell density after a light and then a dark period at two temperatures

(a) The proportion of cells floating, cell density and amounts of major constituents in a culture of Microcystis BC 84/1 were determined after growth at a mean photon flux density of $10 \mu \mathrm{mol} \mathrm{m}^{-2} \mathrm{~s}^{-1}$ and $20^{\circ} \mathrm{C}$ (initial conditions), after exposure of the culture to $50 \mu \mathrm{mol} \mathrm{m}{ }^{-2} \mathrm{~s}^{-1}$ at $8^{\circ} \mathrm{C}$ for $18 \mathrm{~h}(t=18 \mathrm{~h}$ ), and then after dark incubation at $8{ }^{\circ} \mathrm{C}$ for a further $22 \mathrm{~h}(t=40 \mathrm{~h})$. (b) As $(a)$, but culture kept at $20^{\circ} \mathrm{C}$ throughout.

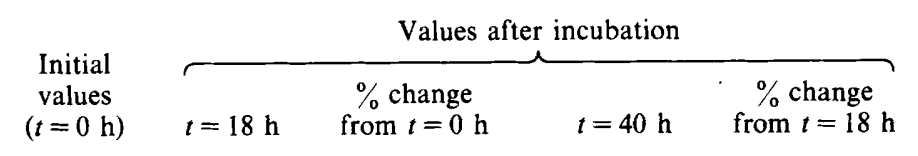

(a) Incubated at $8^{\circ} \mathrm{C}$

Cells floating $(\%)$
Density $\left(\mathrm{kg} \mathrm{m}^{-3}\right)$
Amounts per ml culture:
Dry weight $(\mu \mathrm{g})$
Protein $(\mu \mathrm{g})$
Carbohydrate $(\mu \mathrm{g})$
Gas vesicle space $(\mathrm{nl})$

(b) Incubated at $20^{\circ} \mathrm{C}$

Cells floating $(\%$

Density $\left(\mathrm{kg} \mathrm{m}^{-3}\right)$

Amounts per ml culture:

Dry weight $(\mu \mathrm{g})$

Protein $(\mu \mathrm{g})$

Carbohydrate $(\mu \mathrm{g})$

Gas vesicle space (nl)

$\begin{array}{rr}85 & 8 \\ 1034 & 1043 \\ & \\ 179 & 214 \\ 105 & 101 \\ 15 & 35 \\ \text { ND } & 44 \\ & \\ 85 & 10 \\ 1034 & 1044 \\ & \\ 179 & 223 \\ 105 & 99 \\ 15 & 39 \\ \text { ND } & 46\end{array}$

$\begin{array}{crr} & 16 & \\ & 1042 & \\ \left(+20^{* *}\right) & 209 & (-2 \mathrm{NS}) \\ (-4 \mathrm{NS}) & 105 & (+4 \mathrm{NS}) \\ \left(+133^{* *}\right) & 31 & \left(-11^{* *}\right) \\ - & 45 & (+2 \mathrm{NS}) \\ & 95 & \\ \left(+25^{* *}\right) & 1034 & \\ \left(-6^{*}\right) & 195 & \left(-12^{* *}\right) \\ \left(+160^{* *}\right) & 111 & \left(+17^{* *}\right) \\ - & 14 & \left(-64^{* *}\right) \\ & 49 & \left(+9^{* *}\right)\end{array}$

ND, Not determined.

${ }^{*} t$-test indicates values significantly different at $5 \%$ level; ${ }^{* *}$ significant at $1 \%$ level; NS, not significant at $5 \%$ level.

Buoyancy changes of cells in four cultures maintained on light/dark cycles are shown in Fig. 5. The cultures were kept at temperatures of $8{ }^{\circ} \mathrm{C}$ and $20^{\circ} \mathrm{C}$ and photon flux densities of $20 \mu \mathrm{mol} \mathrm{m}-2 \mathrm{~s}^{-1}$ and $50 \mu \mathrm{mol} \mathrm{m} \mathrm{m}^{-2} \mathrm{~s}^{-1}$ for five complete cycles. At $20^{\circ} \mathrm{C}$ cells at both photon flux densities showed diel regulation of buoyancy, losing buoyancy in the light and recovering it in the dark. However, at $8^{\circ} \mathrm{C}$ recovery in the dark was insufficient to make up for buoyancy lost in the light, causing progressive net loss of buoyancy in each cycle. This buoyancy loss was shown to be reversible by shifting part of the $8{ }^{\circ} \mathrm{C}$ cultures back to $20^{\circ} \mathrm{C}$ after a light period. After $16 \mathrm{~h}$ in the dark at $20^{\circ} \mathrm{C}$ both had increased from around $20 \%$ cells floating to $50 \%$ floating; controls at $8{ }^{\circ} \mathrm{C}$ had shown very small recoveries of buoyancy (Fig. 5).

Growth rates for the four cultures on alternating light/dark $(8 / \overline{16} \mathrm{~h})$ regimes were determined from cell counts. Doubling times were: $3.5 \mathrm{~d}$ at $50 \mu \mathrm{mol} \mathrm{m}^{-2} \mathrm{~s}^{-1}$ and $20^{\circ} \mathrm{C}$; $211 \mathrm{~d}$ at $50 \mu \mathrm{mol} \mathrm{m}-2 \mathrm{~s}^{-1}$ and $8{ }^{\circ} \mathrm{C} ; 5.4 \mathrm{~d}$ at $20 \mu \mathrm{mol} \mathrm{m}^{-2} \mathrm{~s}^{-1}$ and $20^{\circ} \mathrm{C} ; 28 \mathrm{~d}$ at $20 \mu \mathrm{mol} \mathrm{m}^{-2} \mathrm{~s}^{-1}$ and $8^{\circ} \mathrm{C}$. The slow growth rates reflect the failure to produce new cell protein at the lower temperature.

\section{DISCUSSION}

The loss of Microcystis from the plankton to the sediment in Abbots Pool resulted from loss of buoyancy of colonies. The cause of this can be summarized in the following way. In early autumn colonies exhibited diel regulation of buoyancy in response to light. At high photon flux densities near the surface during the day, colonies lost buoyancy; in the dark, in deeper water and at night, buoyancy was regained. The mechanism of light-mediated buoyancy loss is likely to have been accumulation of dense carbohydrate as found in the laboratory strain of Microcystis by Thomas \& Walsby (1985). Some other cyanobacteria are able to lose buoyancy by collapsing their gas 


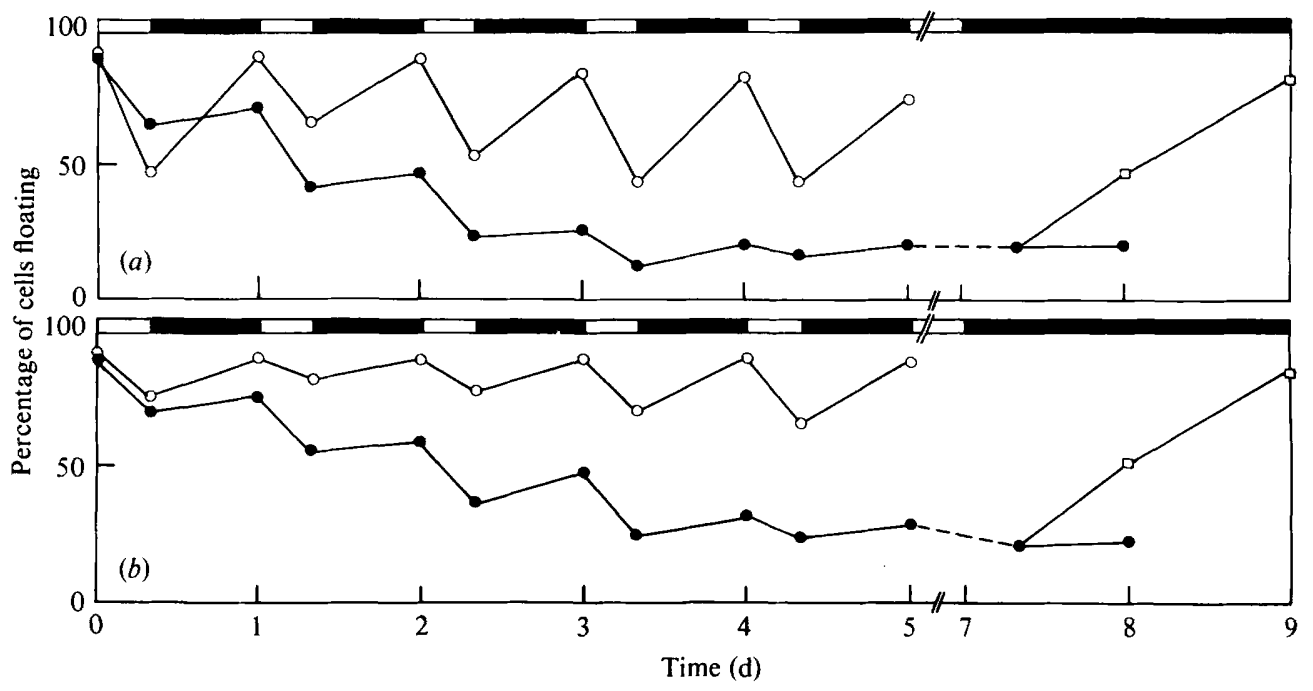

Fig. 5. Changes in the proportion of cells floating in cultures of Microcystis BC 84/1. (a) On cycles of $8 \mathrm{~h}$ light, $50 \mu \mathrm{mol} \mathrm{m} \mathrm{m}^{-2} \mathrm{~s}^{-1}$ (open bar), $16 \mathrm{~h}$ dark (shaded bar) at $20^{\circ} \mathrm{C}(\mathrm{O})$ and $8{ }^{\circ} \mathrm{C}(\mathrm{O}) ;(b)$ as $(a)$ except using a photon flux density of $20 \mu \mathrm{mol} \mathrm{m} \mathrm{m}^{-2} \mathrm{~s}^{-1}$. Samples were transferred from $8^{\circ} \mathrm{C}$ to $20^{\circ} \mathrm{C}$ on day 7 (口).

vesicles under increased turgor pressure (Oliver $\&$ Walsby, 1984). This mechanism could not have operated in the Microcystis from Abbots Pool, however, because its gas vesicles are too strong to be destroyed in this way.

As autumn progressed the water temperature in Abbots Pool decreased and the population of Microcystis colonies gradually lost its buoyancy. It appeared that the reason for this was that colonies near the water surface continued to lose their buoyancy in response to light intensity during the day but they failed to recover their buoyancy subsequently in the dark. This failure could be attributed to the temperature falling below a certain critical value, around $10^{\circ} \mathrm{C}$, at which buoyancy could not be regained sufficiently rapidly in the dark to prevent colonies reaching the sediment.

Once on the sediment, colonies became entrapped there and although they gradually recovered buoyancy through depletion of carbohydrate they were not able to float free. This accounted for the presence of buoyant colonies in the sediment during winter. The colonies that were found in small numbers in the plankton during the winter may have been a residual population that had not sedimented out, or they may have been released from the sediment by disturbance; individual colonies left in suspension may have continued to lose buoyancy on exposure to light and to sink to the sediment during the winter. In the spring, as the water temperature increased, colonies released from the sediment would be able to remain buoyant again, and to grow if other factors permitted.

Experiments with Microcystis BC 84/1, which was shown to behave in a similar manner with respect to temperature, indicated that the magnitude of buoyancy loss in the light was not greatly different at $8{ }^{\circ} \mathrm{C}$ and $20^{\circ} \mathrm{C}$. However, at $8{ }^{\circ} \mathrm{C}$ the rates of protein and gas vesicle synthesis in the dark were greatly reduced, as was the rate at which dense carbohydrate was lost, compared with the activity at $20^{\circ} \mathrm{C}$ (Table 2). There was thus a crucial difference in the relative rates of carbohydrate production in the light and its utilization in the dark between the two temperatures. The resultant buildup of carbohydrate in cells at low temperatures prevented them from regaining buoyancy.

Our results suggest that the ability of Microcystis cells to remain buoyant is linked to their ability to grow by producing protein at the expense of carbohydrate, and that these abilities are therefore similarly sensitive to the effects of temperature. The significance of this is that in a 
lake the organism will fall out of suspension at temperatures where growth cannot occur; overwintering takes place in the sediments.

The results here can be related to other investigations into the effects of light and temperature on other cyanobacteria. Foy (1983) found that carbohydrate changed in a similar manner in two species of Oscillatoria grown on $3 \mathrm{~h}$ light $/ 21 \mathrm{~h}$ dark cycles. At lower temperatures 'dark reactions' in cells were depressed so that the dark period was not long enough for cells to metabolize the store of carbohydrate laid down in the light. Below a critical temperature (11 to $14^{\circ} \mathrm{C}$ ) this resulted in a greater decline in growth rate than predicted by the expected $Q_{10}$ of 2 for light-saturated photosynthesis. Kruger \& Eloff (1978) also found a sharp decline in growth rate below about $15^{\circ} \mathrm{C}$ in four strains of Microcystis, though the exact critical temperature varied between strains. Okino (1973) commented that in several Japanese lakes Microcystis did not appear until the water temperature had reached $20^{\circ} \mathrm{C}$, and again there were indications of strain-specific temperatures. The presence of Microcystis in a lake will be determined not only by its ability to grow but also by its ability to remain in suspension.

We are grateful to J. Kromkamp and Dr A. E. Konopka for discussions on buoyancy changes in light-dark regimes. We thank Miss Annette Bees, Miss K. M. Wade and Miss M. A. J. Williams for assistance with sampling. This work was supported by the NERC with a studentship to R. H.T. and a research grant to A.E.W.

\section{REFERENCES}

FALLON, R. D. \& BROCK, T. D. (1981). Overwintering of Microcystis in Lake Mendota. Freshwater Biology 11, 217-226.

FoY, R. H. (1983). Interaction of temperature and light on the growth rate of two planktonic Oscillatoria species. British Phycological Journal 18, 267273.

Herbert, D., Phipps, P. J. \& Strange, R. E. (1971). Chemical analysis of microbial cells. Methods in Microbiology 5B, 209-344.

KLemer, A. R., Feuillade, J. \& Feuillade, M. (1982) Cyanobacterial blooms: carbon and nitrogen limitation have opposite effects on the buoyancy of Oscillatoria. Science 215, 1629-1631.

KonopKA, A. E. \& BROCK, T. D. (1978). Effect of temperature on blue-green algae (cyanobacteria) in Lake Mendota. Applied and Environmental Microbiology 36, 572-576.

KROMKAMP, J. C. \& MUR, L. C. (1984). Buoyant density changes in the cyanobacterium Microcystis aeruginosa due to changes in the cellular carbohydrate content. FEMS Microbiology Letters 25, 105-109.

KRUGer, G. H. J. \& Eloff, J. N. (1978). The effect of temperature on specific growth rate and activation energy of Microcystis and Synechococcus isolates relevant to the onset of natural blooms. Journal of the Limnological Society of South Africa 4, 9-20.

Moss, B. (1969). Vertical heterogeneity in the water column of Abbots Pond. Journal of Ecology 57, 381396.

OkINo, T. (1973). Studies on the blooming of Microcystis aeruginosa. Japanese Journal of Botany 20, 381402.

Oliver, R. L. \& WALSBY, A. E. (1984). Direct evidence of the role of light-mediated gas vesicle collapse in the buoyancy regulation of Anabaena flos-aquae (cyanobacteria). Limnology and Oceanography 29, 879-886.

Oliver, R. L., Kinnear, A. J. \& Ganf, G. G. (1981). Measurements of cell density of three freshwater phytoplankters by density gradient centrifugation. Limnology and Oceanography 26, 285-294.
Oliver, R. L., Thomas, R. H., ReYnolds, C. S. \& WALSBY, A. E. (1985). The sedimentation of buoyant Microcystis colonies caused by precipitation with an iron containing colloid. Proceedings of the Royal Society B223, 511-528.

REYNolds, C. S. \& Rogers, D. A. (1976). Seasonal variations in the vertical distribution and buoyancy of Microcystis aeruginosa Kütz. emend. Elenkin in Rostherne Mere, England. Hydrobiologia 48, 17-23.

REYNolds, C. S. \& WALSBY, A. E. (1975). Waterblooms. Biological Reviews 50, 437-481.

ReYNolds, C. S., JAworski, G. H. M., CMIECH, H. A. \& LeEDALE, G. F. (1981). On the annual cycle of the blue-green alga Microcystis aeruginosa Kütz. emend. Elenkin. Philosophical Transactions of the Royal Society B293, 419-477.

ROTHER, J. A. \& FAY, P. (1977). Sporulation and development of planktonic blue-green algae in two Salopian meres. Proceedings of the Royal Society B196, 317-332.

Takamura, N., Yasuno, M. \& Sugahara, K. (1984). Overwintering of Microcystis aeruginosa Kütz. in a shallow lake. Journal of Plankton Research 6, 10191029.

Thomas, R. H. \& WalsbY, A. E. (1985). Buoyancy regulation in a strain of Microcystis. Journal of General Microbiology 131, 799-809.

VAN LIERE, L. \& WALSBY, A. E. (1982). Interactions of cyanobacteria with light. In The Biology of Cyanobacteria, pp. 9-45. Edited by N. G. Carr \& B. A. Whitton. Oxford: Blackwell Scientific Publications.

WaLSBY, A. E. (1977). The gas vacuoles of blue-green algae. Scientific American 237, 90-97.

WALSBY, A. E. (1980). The water relations of gasvacuolate prokaryotes. Proceedings of the Royal Society B208, 73-102.

WaLSBY, A. E. (1982). The elastic compressibilility of gas vesicles. Proceedings of the Royal Society B216, 355-368.

WalsBy, A. E. \& Booker, M. J. (1980). Changes in buoyancy of a planktonic blue-green alga in response to light intensity. British Phycological Journal 15, 311-319. 